\author{
https://doi.org/10.34142/23129387.2019.61.08 \\ UDC 159.96 \\ ORCID 0000-0002-2014-4752
}

\title{
PSYCHOLOGICAL FEATURES OF SELF-CONCEPT OF THE TEENAGERS WITH SUBJECTIVE EXPERIENCE OF LONELINESS
}

\author{
Oksana V. Pomazova, \\ graduate student \\ H.S. Skovoroda Kharkiv National Pedagogical University, Ukraine \\ E-mail:o.pomazova@gmail.com
}

Relevance of the problem: Urgency of the research presented in the given paper is caused by spreading of problem of loneliness in the modern society, recognition of loneliness to be one of reasons of teenagers' deviating behavior, lack of researches of correlation between the subjective loneliness experience of teenagers and their self-concept formation as a new formation of the given age.

Aim: determination of specificity of correlation between self-concept and the subjective loneliness experience of teenagers of different age groups.

Methodology of the research: subjective loneliness experience diagnostics by D. Russell and M. Ferguson, teenagers' self-concept research methods by E. Piers and D. Harris in modification of A. M. Prikhozhan (324 pupils of 5-9 forms of 10-15 years old); means of a single-factor analysis of variance, Student t-test for independent samples, and correlation analysis according to Pearson's method.

Results of the research. There are distinctions in self-concept indices of teenagers with various levels of the subjective loneliness experience. It was defined that in the course of time the number of self-concept parameters of the teenagers' connected with the subjective loneliness experience increases. For the group of 10-11 years old teenagers such parameters as anxiety, acceptance of situation at school, self-esteem of physical attraction and satisfaction with communication with age mates are characteristic. In the group of 12-13 years old teenagers the parameters mentioned above are accompanied by self-attitude, satisfaction with life situation, satisfaction with proper position in the family, and in the group of 14-15 years old teenagers - by intelligence self-esteem. In addition, 
frequency and intensity of the subjective loneliness experience has a tendency to increase from 10-11 to 12-13 years old and to further decrease at 14-15 years old.

Keywords: loneliness, subjective loneliness experience, self-concept, teenage years, stable period of teenage years, crisis period of teenage years.

\section{Психологічні особливості Я-концепції підлітків із суб'сктивним переживанням самотності Оксана В. Помазова,}

Харківський національний педагогічний університет імені

$$
\text { Г. С. Сковороди, Україна }
$$

Актуальність проблеми: обумовлена загостренням проблеми самотності в сучасному суспільстві, визнанням почуття самотності однією з причин відхилень у поведіниі підлітків, недостатністю досліджень зв'язку між суб'єктивним переживанням підлітками самотності та формуванням їх Я-концепиії як новоутворення даного віку.

Мета: визначення специфіки взаємозв'язку Я-концепції $i$ суб'єктивного переживання самотності у підлітків різних вікових гpyn.

Методи: методика діагностики рівня суб'єктивного переживання почуття самотності Д. Рассела $i$ M. Фергюсона, методика дослідження Я-кониепиії підлітків Е. Пірса $і$ Д. Харріса 6 модифікаиії А. М. Прихожан (324 учня 5-9 класів віком 10-15 років); однофакторний дисперсійний аналіз, $t$-критерій Стьюдента для незалежних вибірок, кореляиійний аналіз за методом Пірсона.

Результати дослідження. Визначено відмінності в показниках $Я$ концепції підлітків із різними рівнями суб'єктивного переживання самотності. Встановлено, що з віком збільшується кількість параметрів Я-концепиії підлітків, пов'язаних із суб'єктивним переживанням самотності. За групою 10-11-річних підлітків до таких параметрів належать тривожність, сприйняття ситуаиії в иколі, самооцінка зовнішньої привабливості та задоволеності в сфері спілкування з однолітками. За групою 12-13-річних підлітків до даних параметрів додаються ставлення до себе, задоволеності життєвою ситуаиією, задоволеності своїм положенням в сім'ї, а за групою 1415 річних підлітків - самооиінка інтелекту. Разом із тим, частота та інтенсивність суб'єктивного переживання самотності має 
тендениію до збільшення від 10-11 до 12-13 років $і$ подальшого зниження у 14-15-річних підлітків.

Ключові слова: самотність, суб'єктивне переживання самотності, Я-конщепиія, підлітковий вік, стабільний період підліткового віку, кризовий період підліткового віку.

Introduction. Transformation of the modern Ukrainian society is being accompanied by the informational technologies development as well as by decrease of quantity and quality of social contacts, shallow relationships, people's dissatisfaction with a real emotional bond with significant others that causes negative feelings including the feelings of loneliness.

The problem of loneliness at the beginning of its consideration existed as a problem of communication and interpersonal relations. In recent years, new scientific researches appear where loneliness is associated with personality's characteristics. A person can feel oneself lonely regardless the number of people related. Loneliness in this respect is an inner, subjective experience.

K. Rubinstein and F. Shaver understand the subjective loneliness experience as being perceived by different people in a different way: "for one person this is a feeling of despair for the lost love or a close friend; for another one - a temporary feeling of boredom due to lack of communication; for the third one it can appear as part of the general disengagement, a feeling of proper noncompliance" (Rubinstein, Shaver, 1989, p. 337).

S. G. Korchagina emphasizes the subjective, inner determinants of loneliness and defines loneliness as personality's mental state reflecting experience of proper singularity, subjective impossibility or unwillingness to feel an adequate response, proper acceptance and recognition by other people (Korchagina, 2005, p. 14).

L. Peplau, M. Miceli and B. Morasch point out that in the same social relationships one person feels lonely and another one is fully satisfied as the feeling of loneliness becomes stronger or weaker depending on changes in the subjective standards of personality regarding his/her relationships (1989, p. 172). Definition of proper loneliness is a result of the long-lasting cognitive, affective and 
behavioral processes thanks to which proper experience is realized, comprehended and generalized into the whole concept.

E. M. Zavorotnykh considers loneliness as the subjective experience relatively independent from the number and character of interpersonal contacts of a person arousing both negative and positive feelings and based on personality's subjective evaluation of proper loneliness due to the inner perception of proper experience. Thus, it is not the external, objective situation of interpersonal interaction but its internal, subjective perception that is a determinant one. Loneliness as a subjective experience is not influenced by personality's age and may not be realized by personality or is partially and perversely realized or consciously turned down. In author's opinion all people are in constant loneliness of different level. Hereof, the idea od absence of loneliness is understood as availability of loneliness in theform optimal for personality (Zavorotnykh, 2009).

The researches focused on studying of teenagers' loneliness experience identify types of loneliness and disengagement correlation (Dolginova, 1996), situational and personal determinants of loneliness experience (Koroteeva, 2011), specificity of loneliness experience by teenagers with different social orientation (Rogovaya, 2007). Loneliness experience is associated with personal characteristics of teenagers (modesty, inability to establish interpersonal contacts, fear of rejection, low self-esteem, low level of self-respect, negative self-attitude), special aspects of teenage years as one of the most crisis periods in personality's life (Mironets, 2013; Rogovaya, 2007), self-consciousness and reflection establishment, self-concept formation (Slobodchikov, 2006). However, no broad picture of psychological constitution of self-consciousness and selfconcept of teenagers with the subjective loneliness experience is presented in the scientific researches nowadays.

Aim. The aim of the article is to identify specificity of correlation between self-concept and the subjective loneliness experience of teenagers of different age groups.

Methodology of research. The research of the subjective loneliness experience was conducted by usage of Russell-Ferguson's 
methodology. The given methodology is aimed to test the level (of frequency and intensity) of the subjective loneliness experience. Personalities with a low level experience loneliness very seldom, only in force-majeure circumstances, or this feeling is unknown to them. Personalities with an average level experience loneliness from time to time in particular situations. Personalities with a high level experience loneliness often and keenly.

Self-concept of teenagers was studied by means of methodology of E. Piers and D. Haris in modification of A. M. Prikhozhan. This methodology is based on views of the authors who consider selfconcept as a complex psychological formation including a system of personality's self-esteems and attitudes connected with his/her behavior in various spheres and the social contacts system. The given methodology helped to determine the social desirability of personality's responses, general self-satisfaction, and positivity of self-attitude. Moreover, self-concept special aspects are studied by particular indices: behavior (correspondence of behavior to the adults' demands); intelligence, status at school, school performance; situation at school (evaluating a situation as an unfortunate, neutral or positive one), appearance, physical attraction, physical development as qualities connected with popularity among age mates; anxiety (a low adaptive, average or high level); communication, popularity among age mates, self-esteem of communication ability; happiness and satisfaction with life; position in the family (level of satisfaction with proper position in the family); self-confidence.

Mathematical and statistical data processing was conducted by means of a single-factor analysis of variance, Student t-test for independent samples, and correlation analysis according to Pearson's method.

The study engaged 324 teenagers - pupils of 5-9 forms of general academic schools of Donetsk, Dnepropetrovsk, Kiev and Kharkov of 10-15 years old. In order to obtain more differential data within this age period three age groups were formed out: 83 teenagers of 10-11 years old, 128 teenagers of 12-13 years old, 113 
teenagers of 14-15 years old who are conditionally specified as early, middle and late teenagers.

The above-noted age intervals were determined on basis of analysis of development social situation peculiarities at every age interval. Moreover, while dividing teenagers into groups we considered the modern researchers' ideas of the crisis and stable periods within teenage years. According to K. M. Polivanova (2000), the crisis period lasts from 10,6 to $12-13$ years old and the stable period - from 14 to 15 years old. The crisis peak point falls at 11,8 years old. According to M.M. Smirnyagina (2009) on the grounds of the results of the research specially conducted the crises period falls at 10,6-13 years old and the stable development period is characteristic for 14-15 years old. A. A. Katerinina's dissertation research (2013) proved that a transition period from a younger schoolchild to an early teenager including 10-11 years old age interval is a full-featured development crisis. Solving of the given crisis is connected with changing of teenagers' attitude to their adults, age mates and them-selves.

Results. The diagnostics results of the subjective loneliness experience level showed that among early teenagers $17,81 \%$ being investigated are characterized by high level of the subjective loneliness experience, $39,72 \%$ - by average level, $42,47 \%$ - by low level. Middle teenagers with high level of the subjective loneliness experience are $25 \%$ of teenagers of the given group, with average level $-42 \%$, with low level- $33 \% .20 \%$ of the investigated late teenagers are characterized by high level of the subjective loneliness experience, $44 \%$ - by average level, $36 \%$ - by low level. Average index of the subjective loneliness experience of early teenagers is $23,39 \pm 13,7$, middle teenagers - $25,89 \pm 14,8$, late teenagers $25,31 \pm 14,2$.

The groups of early teenagers with various levels of the subjective loneliness experience differ substantially upon the following self-concept indices: situation at school; appearance, physical attraction, physical development as characteristic connected with popularity among age mates; anxiety; communication, popularity among age mates, communication ability (Table 1). 
Early teenagers with high level of the subjective loneliness experience are more inclined to evaluating a situation at school as an unfortunate or neutral one, in comparison with early teenagers with low and average levels of the subjective loneliness experience. The latest ones evaluate situation at school as a positive one.

Table 1

Average values of self-concept indices of early teenagers at school with different level of the subjective loneliness experience

\begin{tabular}{|l|c|c|c|c|c|}
\hline \multirow{2}{*}{ Self-concept indices } & \multicolumn{3}{|c|}{$\begin{array}{l}\text { Level of the subjective } \\
\text { loneliness experience }\end{array}$} & \multirow{2}{*}{$\mathrm{F}$} & \multirow{2}{*}{$\mathrm{p}$} \\
\cline { 2 - 4 } & low & average & high & & \\
\hline self-attitude & 57,90 & 54,17 & 51,00 & 2398 & 0,097 \\
\hline behavior & 9,59 & 8,79 & 9,47 & 1,244 & 0,294 \\
\hline $\begin{array}{l}\text { intelligence, status at } \\
\text { school }\end{array}$ & 9,97 & 9,72 & 8,87 &, 735 & 0,483 \\
\hline situation at school & 4,92 & 5,00 & 3,33 & 11,376 & 0,000 \\
\hline $\begin{array}{l}\text { appearance, physical } \\
\text { attraction }\end{array}$ & 8,59 & 7,86 & 7,13 & 3,132 & 0,049 \\
\hline anxiety & 3,41 & 4,21 & 4,73 & 3,464 & 0,036 \\
\hline communication & 12,97 & 12,03 & 9,40 & 4,956 & 0,009 \\
\hline $\begin{array}{l}\text { happiness and } \\
\text { satisfaction }\end{array}$ & 7,15 & 6,83 & 6,33 & 1,203 & 0,306 \\
\hline position in the family & 5,77 & 5,45 & 5,60 &, 320 & 0,727 \\
\hline self-confidence & 12,74 & 12,55 & 12,53 &, 051 & 0,951 \\
\hline
\end{tabular}

Early teenagers with high level of the subjective loneliness experience differ by lower level of self-esteem of appearance, proper physical qualities, proper communication ability, in comparison with early teenagers of other two groups. The highest level of self-esteem of proper physical attraction, communication ability is determined for early teenagers with low level of the subjective loneliness experience.

The groups of middle teenagers with various levels of the subjective loneliness experience differ substantially upon the following Self-concept indices: self-attitude; situation at school; appearance, physical attraction, physical development; anxiety; 
communication, popularity among age mates, communication ability, happiness and life satisfaction (Table 2).

Table 2

Average values of self-concept indices of middle teenagers at school with different level of the subjective loneliness experience

\begin{tabular}{|l|c|c|c|c|c|}
\hline \multirow{2}{*}{ Self-concept indices } & \multicolumn{3}{|c|}{$\begin{array}{l}\text { Level of the subjective } \\
\text { loneliness experience }\end{array}$} & \multirow{2}{*}{$\mathrm{F}$} & \multirow{2}{*}{$\mathrm{p}$} \\
\cline { 2 - 4 } & low & average & high & & \\
\hline self-attitude & 57,69 & 55,17 & 49,31 & 7,763 & 0,001 \\
\hline behavior & 9,00 & 8,59 & 9,16 &, 871 & 0,421 \\
\hline $\begin{array}{l}\text { intelligence, status at } \\
\text { school }\end{array}$ & 9,62 & 9,17 & 9,00 &, 548 & 0,580 \\
\hline situation at school & 5,00 & 4,72 & 3,78 & 8,934 & 0,000 \\
\hline $\begin{array}{l}\text { appearance, physical } \\
\text { attraction }\end{array}$ & 8,76 & 8,44 & 6,72 & 10,131 & 0,000 \\
\hline anxiety & 3,02 & 4,00 & 5,13 & 9,721 & 0,000 \\
\hline communication & 13,31 & 13,17 & 9,66 & 11.486 & 0,000 \\
\hline $\begin{array}{l}\text { happiness and } \\
\text { satisfaction }\end{array}$ & 7,74 & 7,22 & 6,53 & 5,960 & 0,003 \\
\hline position in the family & 6,17 & 5,46 & 5,50 & 2,303 & 0,104 \\
\hline self-confidence & 12,07 & 12,09 & 11,91 &, 048 & 0,954 \\
\hline
\end{tabular}

Middle teenagers with high level of the subjective loneliness experience in comparison with their age mates with low and average levels of the subjective loneliness experience are more inclined to more negative self-attitude, evaluating a school situation as an unfortunate or neutral one, lower level of self-esteem of physical attraction and qualities, communication abilities, lower level of satisfaction with life situation and higher anxiety level.

Middle teenagers with low and average levels of the subjective loneliness experience, inversely, differ by more positive self-attitude, evaluating a school situation as a positive one, high self-esteem of physical attraction, high and average self-esteem of communication abilities, full feeling of satisfaction with life situation. According to the given self-concept factors there are no statistically significant differences between the groups of middle teenagers with low and 
average level of the subjective loneliness experience. However, middle teenagers with low level of the subjective loneliness experience appeared to be less anxious in comparison with their age mates with an average level of the subjective loneliness experience $(\mathrm{t}=2,424 ; \mathrm{p}<0,05)$.

The groups of late teenagers with various levels of the subjective loneliness experience differ substantially upon the following self-concept indices: self-attitude; intelligence, status at school; situation at school; appearance, physical attraction, physical development; anxiety; communication, popularity among age mates, communication ability; happiness and life satisfaction, position in the family (Table 3 ).

Table 3

Average values of self-concept indices of late teenagers at school with different level of the subjective loneliness experience

\begin{tabular}{|l|c|c|c|c|c|}
\hline \multirow{2}{*}{ Self-concept indices } & \multicolumn{3}{|c|}{$\begin{array}{l}\text { Level of the subjective } \\
\text { loneliness experience }\end{array}$} & \multirow{2}{*}{$\mathrm{F}$} & \multirow{2}{*}{$\mathrm{p}$} \\
\cline { 2 - 5 } & low & average & high & & \\
\hline self-attitude & 57,40 & 56,42 & 44,52 & 16,028 & 0,000 \\
\hline behavior & 9,40 & 9,52 & 8,57 & 1,641 & 0,199 \\
\hline $\begin{array}{l}\text { intelligence, status at } \\
\text { school }\end{array}$ & 9,95 & 9,60 & 6,83 & 10,073 & 0,000 \\
\hline situation at school & 4,73 & 4,64 & 3,74 & 4,354 & 0,015 \\
\hline $\begin{array}{l}\text { appearance, physical } \\
\text { attraction }\end{array}$ & 8,70 & 8,22 & 6,83 & 5,439 & 0,006 \\
\hline anxiety & 3,65 & 3,92 & 5,65 & 8,245 & 0,000 \\
\hline communication & 12,90 & 13,38 & 9,91 & 4,999 & 0,008 \\
\hline $\begin{array}{l}\text { happiness and } \\
\text { satisfaction }\end{array}$ & 7,43 & 7,32 & 5,87 & 7,540 & 0,001 \\
\hline position in the family & 6,28 & 6,14 & 4,52 & 9,058 & 0,000 \\
\hline self-confidence & 12,15 & 12,04 & 11,61 &, 215 & 0,807 \\
\hline
\end{tabular}

Late teenagers with high level of the subjective loneliness experience are different from their age mates with average and low level of the subjective loneliness experience by more negative selfattitude, lower self-esteem of intelligence and school achievement, 
evaluating a school situation as an unfortunate or neutral one, lower level of self-esteem of physical attraction, communication abilities, lower level of satisfaction with life situation and position in the family, but higher anxiety level.

Late teenagers with low and average levels of the subjective loneliness experience, inversely, differ by more positive self-attitude, evaluating a school situation as a positive one, high self-esteem of physical attraction, high and average self-esteem of intelligence, school achievement, communication abilities, full feeling of satisfaction with life situation and position in the family, low (adaptive) anxiety level. According to the given self-concept factors there are no statistically significant differences between the groups of late teenagers with low and average level of the subjective loneliness experience.

According to the correlation analysis results, the subjective loneliness experience of early teenagers has inverse correlation with such self-concept factors as situation at school, physical attraction, communication, and has direct correlation with anxiety (Table 4).

Table 4

Correlation of the subjective loneliness experience and selfconcept indices of teenagers of different age

\begin{tabular}{|l|c|c|c|}
\hline \multirow{2}{*}{ Self-concept indices } & \multicolumn{3}{|c|}{ Teenage groups } \\
\cline { 2 - 4 } & early & middle & late \\
\hline self-attitude & $-0,202$ & $-0,324^{* *}$ & $-0,454^{* *}$ \\
\hline behavior & $-0,052$ & 0,014 & 0,149 \\
\hline intelligence, status at school & $-0,090$ & $-0,105$ & $-0,319^{* *}$ \\
\hline situation at school & $-0,395^{* *}$ & $-0,360^{* *}$ & $-0,302^{* *}$ \\
\hline $\begin{array}{l}\text { appearance, physical } \\
\text { attraction }\end{array}$ & $-0,218^{*}$ & $-0,376^{* *}$ & $-0,304^{* *}$ \\
\hline anxiety & & & \\
\hline communication & $0,248^{*}$ & $0,404^{* *}$ & $0,398^{* *}$ \\
\hline happiness and satisfaction & $-0,265^{*}$ & $-0,328^{* *}$ & $-0,323^{* *}$ \\
\hline position in the family & $-0,170$ & $-0,324^{* *}$ & $-0,372^{* *}$ \\
\hline self-confidence & $-0,005$ & $-0,185^{*}$ & $-0,331^{* *}$ \\
\hline
\end{tabular}

Note: $*-\mathrm{p}<0,05, * *-\mathrm{p}<0,01$

In the group of 12-13 years old teenagers' intensity and frequency of the subjective loneliness experience is accompanied by: 
anxiety level increase; self-attitude level decrease; decrease of satisfaction with life situation in which they stay; decrease of satisfaction with family position; decrease of positivity in evaluation of school situation, self-esteem of physical attraction and popularity among age mates, communication ability.

As regards the group of late teenagers, all the regularities mentioned for the group of 12-13 years old teenagers relate to this group as well as inverse correlation of intensity and frequency of the subjective loneliness experience with level of self-esteem of intelligence, status at school, school success level.

Discussion. Based on the results of the research conducted, we determined the tendency to frequency and intensity increase of the subjective loneliness experience of teenagers from 10-11 to 12-13 years old and decrease of this tendency up to 14-15 years old. The obtained data are in agreement with research results of O. M. Koroteeva (2011) who found that teenagers of 12-13 years old experience loneliness more often than teenagers of 10-11 and 14-15 years old. E. E. Rogovaya (2007) determined the gradual decrease of severity of the subjective loneliness experience from early to late teenage age, however, her research considered the group of early teenagers as 12-14 years old schoolchildren, and late teenagers - 1517 years old schoolchildren. The group of 10-11 years old teenagers was not presented in E. E. Rogovaya's research.

O. B. Dolginova (1996) points out that loneliness as psychological state arises to teenagers in case they have a feeling of disengagement called by relationships with mother, father, other family members. Moreover, the researcher notes that teenagers' loneliness experience firstly correlates to insolvability of problem of significant level relationships with age mates. The determined correlation between teenagers' anxiety and frequency of their loneliness experience is explained by O. B. Dolginova (1996) that anxiety source for teenagers, first of all, is psychological disengagement of the family and the problem of relationships with age mates is activated only in youth.

In Y. V. Zheleznyakova's opinion (2013), the feeling of loneliness originates at teenage years in the family and depends on 
the upbringing style and specificity of relationships between family members who further become a reason of formation of teenagers' modesty, aggressiveness, anxiety. The given features combined with school life problems make teenagers' socialization and social adaptation more complicated that eventually leads to intensification of the subjective loneliness experience.

According to the data from the conducted research, there is intensity and frequency increase of the subjective loneliness experience of teenagers of all three age groups alongside with anxiety level increase, decrease of self-esteem level of popularity among age mates, proper communication abilities, self-esteem of physical attraction, and positivity of evaluating a situation at school. Satisfaction with proper position in the family appeared to correlate to the subjective loneliness experience in the groups of 12-13-years old and 14-15 years old teenagers. Herewith, the strength of the given correlation increases while passing to late teenage years that is confirmed by occurrence of differences in indices of satisfaction with position in the family between teenagers with different levels of the subjective loneliness experience only in the group of late teenagers.

The results obtained by us may be considered in the aspect illustrated in the research of A. A. Katerinina (2013). The researcher points out that an early teenager at school changes his attitude to an adult, first of all, to a teacher, age mates, to oneself. Holistic evaluation of a teacher is changed by orientation to his/her personal and professional characteristics. Constant and holistic evaluation of age mates is changed by meaningful and diversified one (when applicable). Simultaneous orientation to I-real and I-ideal becomes a background for early teenagers' self-attitude. The mentioned changes happen in the following sequence: at first, changes happen in relationships with adults, later - in relationships with age mates, and, finally, a new self-attitude is formed. Therefore, intensity and frequency of the loneliness experience by early teenagers is essentially connected with self-concept aspects which are formed under the influence of school situation, the positivity of which is defined by a teenager not only by satisfaction of communication with age mates, being accepted by them but also by specificity of 
relationships with a teacher. The older teenagers become, the stronger loneliness experience increase is connected with dissatisfaction with proper position in the family.

Negative correlation of the subjective loneliness experience and teenagers' evaluation of their proper physical appearance as a quality connected with popularity among age mates is identified in three age groups of teenagers. This negative correlation supplements I. M. Slobodchikov's data (2005) regarding teenagers' sensibility to evaluation of their appearance by other people and influence of these evaluations on teenagers' self-esteem and their personal development in general. We can note that the influence of appearance self-esteem on frequency and intensity of the subjective loneliness experience is already characteristic for early teenagers and remains until they become late teenagers.

Conclusions. According to the results of the research conducted, there's confirmation of differences availability in selfconcept indices of teenagers with different levels of the subjective loneliness experience. It was established that intensity and frequency of the subjective loneliness experience of early teenagers of 10-11 years old has direct correlation with anxiety, and has inverse correlation with positivity of acceptance situation at school, selfesteem of physical attraction and satisfaction with age mates communication. The group of 12-13 years old teenagers except of regularities peculiar to early teenagers is characterized by increase of the subjective loneliness experience while decrease of level of selfattitude, satisfaction with life situation, satisfaction with proper position in the family. The group of 14-15 years old teenagers alongside with regularities identified in the groups of 10-11 and 1213 years old teenagers are characterized by the inverse correlation of intensity and frequency of the subjective loneliness experience with level of intelligence self-estieem. Therefore, the number of teenagers' self-concept parameters connected with the subjective loneliness experience increases alongside with their ages. Moreover, frequency and intensity of the subjective loneliness experience have a tendency to increase from 10-11 to 12-13 years old and further decrease at 14-15 years old teenagers. 


\section{References}

Dolginova, O. B. (1996). Odinochestvo i otchuzhdennost v podrostkovom i iunosheskom vozraste [Loneliness and disengagement in teenage and juvenile years] (Abstract of dissertation of Candidate of Psychological Sciences). The Herzen State Pedagogical University of Russia, Saint-Petersburg [in Russian].

Zhelezniakova, Yu. V. (2013). Samotnist u pidlitkovomu vitsi yak sotsialno-psykholohichna problema [Loneliness in teenage years as a sociopsychological problem]. Bulletin of the University of Dnipropetrovsk. "Pedagogocs and Psychology" Vol. 19. pp. 67-74 [in Ukrainian].

Zavorotnykh, E. N. (2009). Sotsialno-psikhologicheskie osobennosti odinochestva kak subieektivnogo perezhivaniia [Socio-psychological peculiarities of loneliness as a subjective experience] (Dissertation of Candidate of Psychological Sciences).). Saint-Petersburg State University, Saint-Petersburg [in Russian].

Katerinina, A. A. (2013). Psikhologicheskoe soderzhanie perekhodnogo perioda ot mladshego shkolnogo $\mathrm{k}$ mladshemu podrostkovomu vozrastu [Psychological content of the transaction period from primary school age to early teenage age] (Abstract of dissertation of Candidate of Psychological Sciences). Russian State University for the Humanities, Moscow [in Russian].

Koroteeva, E. M. (2011). Situatsionnye, lichnostnye determinanty i tipy odinochestva podrostkov [Situational, personal determinants and types of teenage loneliness] (Abstract of dissertation of Candidate of Psychological Sciences). Kuban State University, Krasnodar [in Russian].

Korchagina, S. G. (2005). Genezis, vidy i proiavleniia odinochestva [Genesis, types and manifestations of loneliness]. Moscow: Moscow Psychological and Social Institute [in Russian].

Myronets, M. H. (2013). Psykholohichni osoblyvosti perezhyvannia samotnosti v pidlitkovomu vitsi [Psychological peculiarities of loneliness experience in teenage years]. Science and education, 1-2, 66-68 [in Ukrainian].

Peplo, L. E., Mitseli, M., Morash, B. (1989). Odinochestvo i samootsenka [Loneliness and self-esteem]. N. E. Pokrovsky (Eds.), Loneliness labyrinths (pp. 169-191). Moscow: Progress [in Russian].

Polivanova, K. N. (2000). Psikhologiia vozrastnykh krizisov [Psychology of developmental crisis]. Moscow: Academy [in Russian]. 
Rogova, E. E. (2007). Perezhivanie odinochestva podrostkami s raznoi sotsialnoi napravlennostiu [Loneliness experience of the teenagers with different social orientation]. Psychology issue, 5, 39-46 [in Russian].

Rubinstain, K., Sheiver, F. (1989). Odinochestvo v dvukh gorodakh Severo-Vostoka [Loneliness in two cities of the North-East]. N. E. Pokrovsky (Eds.), Loneliness labyrinths (pp. 320-342). Moscow: Progress [in Russian].

Slobodchikov, I. M. (2005). Perezhivanie odinochestva v ramkakh formirovaniia «Ia-kontseptsii» podrostkovogo vozrasta [Loneliness experience within formation of teenagers' self-concept]. Psychological Science and Education, 1, 28-32 [in Russian].

Slobodchikov, I. M. (2006). Teoretiko-eksperimentalnoe issledovanie fenomena odinochestva lichnosti (na materiale podrostkovogo vozrasta) [Theoretical and experimental research of personality's loneliness phenomenon (based on the teenage age material)] (Abstract of the dissertation of a doctor of psychological sciences). Russian State University for the Humanities, Moscow [in Russian].

Smirniagina, M. M. (2009). Vozrastnye granitsy i psikhologicheskoe soderzhanie stabilnogo perioda podrostkovogo vozrasta [Age limits and psychological content of the teenage age stable period]. Bulletin of South Ural State University. Psychology, 5 (138), 56-61[in Russian].

Оригінальний рукопис отриманий 23 травня 2019 року

Стаття прийнята до друку 30 травня 2019 року 